\title{
Proximate, Minerals, and Amino Acid Compositions of Banana and Plantain Peels
}

\author{
${ }^{*}$ Tsado Amos Ndarubu, ${ }^{2}$ Okoli Nnenna Rosemary, ${ }^{3}$ Jiya Abel Gboke, ${ }^{4}$ Gana David, ${ }^{1}$ Saidu \\ Binta, ${ }^{1}$ Zubairu Rukiya, ${ }^{1}$ Salihu Ibrahim Zungeru
}

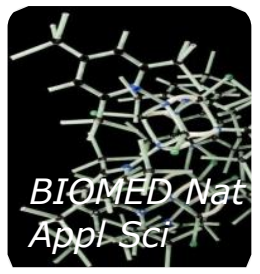

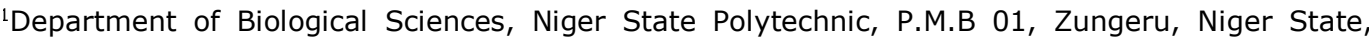 \\ Nigeria \\ 'Department of Science Laboratory Technology, Federal Polytechnic Oko, Anambra State, Nigeria. \\ ${ }^{3}$ Department of Biological Sciences, Federal Polytechnic, Bida, Niger State, Nigeria. \\ ${ }^{7}$ Department of Geography and Environmental Management, University of Abuja, Nigeria
}

\begin{abstract}
The by-products of banana and plantain fruits, especially banana and plantain peels are usually thrown away by producers in plantations, and produce important quantities of post-harvest waste. The banana and plantain peels grown in Nigeria was assessed for their proximate, minerals and amino acid compositions. The proximate contents including moisture, ash, lipids, proteins, carbohydrates and crude fibres were determined using standard A.O.A.C methods. The amino acids by HPLC, and minerals by atomic absorption spectrophotometry. Results revealed that the total amino acid of $89.71 \pm 5.45 \mathrm{~g} / 100 \mathrm{~g}$ and $86.71 \pm 3.02 \mathrm{~g} / 100 \mathrm{~g}$ was recorded for plantain and banana peel. Glutamic acid $12.72 \pm 0.02 \mathrm{~g} / 100 \mathrm{~g}$ was the most abundant amino acid in plantain peel while glycine $(3.02 \pm 0.82 \mathrm{mg} / 100 \mathrm{~g})$ was the most abundant amino acid in banana peel. Results revealed that sodium is the most abundant minerals contents of both the plantain $(76.88 \pm 0.89 \mathrm{Mg} / 100 \mathrm{~g})$ and banana $(58.16 \pm 2.73 \mathrm{Mg} / 100 \mathrm{~g})$ peel, while iron $(7.89 \pm 0.79 \mathrm{Mg} / 100 \mathrm{~g}$ and $5.06 \pm 0.07 \mathrm{Mg} / 100 \mathrm{~g})$ was the least minerals in the both samples. Carbohydrate is the most abundant proximate contents of both the plantain (74.12 \pm 0.565$)$ and banana (63.82 $\pm 0.32 \%)$ peel, followed by Crude fibre $8.36 \pm 0.04 \%$ and $12.67 \pm 0.08 \%$, crude ash $(6.17 \pm 0.05 \%$ and $9.56 \pm 0.06 \%)$ for both plantain and banana peels respectively. While crude fat (3.01 $\pm 0.06 \%$ and $0.89 \pm 0.04 \%$ ) was the least proximate in the both samples. These peels could be considered good source of nutrients for production of human and animal feeds, and their utilization for this purpose should be encouraged, as this will also help in reducing the menace of nutrient deficiencies.
\end{abstract}

\section{Keywords: Proximate composition, Minerals composition, Amino Acid profile, Banana and} Plantain Peels

Received: 28 January 2021, Revised: 16 April 2021, Published: 05 May 2021;

CONTACT: Tsado Amos Ndarubu, Department of Biological Sciences, Niger State Polytechnic, P.M.B 01, Zungeru, Niger State, Nigeria infoamosndarubu@gmail.com, Mobile-+2348032920909

Citation: Tsado, A.N., Okoli, N.R., Jiya, A.G., Gana, D., Saidu, B., Zubairu, R., and Salihu, I. Z. (2021). Proximate, Minerals, and Amino Acid Compositions of Banana and Plantain Peels. BIOMED Natural and Applied Science, 01, (01); 032-042

\subsection{INTRODUCTION}

Banana and plantain plants are the world's biggest herbs, grown abundantly in many developing countries. Bananas and plantains are one of the most important sources of energy in the diet of people living in tropical humid regions (Florenta, et al., 2015). They belong to the family Musaceae and the genus Musa. Musa paradisiaca, are collectively known as banana (English), 'Ogede agbagba' (Yoruba), 'Ayaba' (Hausa) and 'Ogadejioke' (Igbo). The plant consists of long, overlapping leafstalks and bears a stem which is 1.22 to $6.10 \mathrm{~m}$ high (Oladiji et al., 2010), with a life span of about 15 years (Philips, 1982).

The fruits grow in clusters, each separate banana of the cluster being about 1 inch in diameter and somewhat longer than a banana fruit. Banana and plantains fruit requires about two and a half to four months after shooting before the fruit becomes ready for harvesting or a total of about eight to twelve months after planting (Swennen, 1990). 
Banana and plantains contains high fibre content, and thus is capable of lowering cholesterol and helps to relieve constipation and hence prevention of colon cancer. Besides this, its high potassium content is found to be useful in the prevention of raising blood pressure and muscle cramp ( $\mathrm{Ng}$ and Fong, 2000). Various parts of the plant such as the leaves, root, fruit stalk, bract and fruit have been used for medicinal and domestic purposes.

The fruit is consumed as food, the leaf juice is used in the treatment of fresh wounds, cuts and insect bites while the leaves act as an arbortifacient. Its sap is used as a remedy for diarrhoea, dysentery, hysteria and epilepsy. A cold infusion of the root is used to treat venereal diseases and anaemia. In addition, the fruit has been reportedly used as antiscorbutic, aphrodisiac and diuretic (Gill, 1992). Adeniji, et al., (2006) reported 100g edible portion of banana to contain $67.30 \mathrm{~g}$ moisture, $0.4 \mathrm{~g}$ crude fat, $31.15 \mathrm{~g}$ carbohydrate, 0.95 mg potassium, $35.1 \mathrm{mg}$ sodium, $71.5 \mathrm{mg}$ calcium, $28 \mathrm{mg}$ phosphorus, $2.4 \mathrm{mg}$ iron, and yielded $116 \mathrm{kcal}$ of energy.

Banana and plantain peels are by-products of the banana and plantain processing industry, which are normally dumped in landfills, rivers or unregulated grounds (Osma et al., 2007). The peel of the fruit is discarded as waste after the inner fleshy portion has been eaten, thereby constituting a menace to the environment, especially where its consumption is common. Omole et al (2008) reported that the peel has the potentials of replacing corn starch in the diet of snail, while the bracts, fruit stalk and leaf at times are left in the farm as wastes. Leaves, pseudostems, fruit stalks and peels, after chopping, fermentation, and drying, yield a meal somewhat more nutritious than alfalfa press-cake. These waste materials have been considered for use as organic fertilizer in Somalia. In Malaya, pigs fed with pseudostems are less prone to liver and kidney parasites than those on other diets.

Banana and plantain peels are readily available agricultural waste that is underutilized as potential growth medium for yeast strain, despite their rich carbohydrate content and other basic nutrients that can support yeast growth (Lim, 2009). Based on research, banana and plantain peels are convenient, non-toxic and ecofriendly ash to compatible as matrix for producing mulching film. Reported in from study found that micronutrients such as iron and zinc were found in higher concentration in banana peels compare to pulps (Panda, 2013). Upon ripening, several degradative reactions caused by endogenous enzymes are believed to affect starch and hemicelluloses composition of the peels and this explains its elevated sugar content. This chemical conversion process makes biodegradation of waste banana peel easy when needed for other biotechnological use (Steven, 2012). In view of the need for waste management and upsurge in the prizes of livestock and human feeds coupled with their increasing demand, it become relevant to determine the nutrients compositions of banana and plantain peel for possible utilization as livestock feeds.

\subsection{MATERIAL AND METHOD}

\subsection{Sample Collection}

The plantain and banana peels were obtained from Bosso market in Minna, Niger state, Nigeria. Taxonomic authentication of the plant was conducted by at the Department of Biology, Federal University technology, Minna Niger State, Nigeria

\subsection{Preparation of the plant}

The peels were washed, allowed to drain and placed on a foil paper. The peels were air dried for 2 weeks. The dried samples were pulverized using electronic blending machine and stored in plastic container prior to the analysis

\subsection{Proximate Analysis}

The proximate analysis of the sample was carried out by the methods of AOAC, (1990)

\subsubsection{Moisture}

Moisture was determined by oven drying method. Two $(2 \mathrm{~g})$ of the sample was accurately weighed into a separate clean, dried crucible $\left(\mathrm{W}_{1}\right)$. Each crucible was allowed in an oven at $100-105^{\circ} \mathrm{C}$ for 6 - 12 hrs until a

Citation: Tsado, A.N., Okoli, N.R., Jiya, A.G., Gana, D., Saidu, B., Zubairu, R., and Salihu, I. Z. (2021). Proximate, Minerals, and Amino Acid Compositions of Banana and Plantain Peels. BIOMED Natural and Applied Science, 01, (01); 032-042 
constant weight was obtained. Then the crucible was placed in the desiccator for $30 \mathrm{~min}$ to cool. After cooling, it was weighed again $\left(\mathrm{W}_{2}\right)$. The percentage moisture content was determined as follows:

$\%$ Moisture $=\frac{W_{1}-W_{2} \times 100}{\text { Weight of leaf }}$

Where

$$
\begin{aligned}
& \mathrm{W}_{1}=\text { Initial weight of crucible }+ \text { Sample } \\
& \mathrm{W}_{2}=\text { Final weight of crucible }+ \text { Sample }
\end{aligned}
$$

\subsubsection{Ash}

The determination of ach in the sample was carried by placing a clean empty crucible (W1) in a muffle furnace at $550^{\circ} \mathrm{C}$ for an $\mathrm{hr}$, cooled in a desiccator. Two gram $(2 \mathrm{~g})$ of the sample was placed in the crucible $\left(\mathrm{W}_{2}\right)$ and was ignited over a burner, until it was charred. Then the crucible was placed in a muffle furnace for ashing at 550 ${ }^{\circ} \mathrm{C}$ for 2-4 $\mathrm{h}$. The appearance of gray white ash indicated complete oxidation of all organic matter in the sample. After ashing the crucible was cooled and weighed $\left(\mathrm{W}_{3}\right)$. Percentage ash was determined as follows:

$\%$ Ash $=\quad$ Difference in Weight of Ash $\times 100$

$$
\begin{gathered}
\text { Weight of leaf } \\
\text { Difference in weight of ash }=W_{3}-W_{1}
\end{gathered}
$$

\subsubsection{Crude Protein}

Protein content of the sample was determined by Kjeldahl method. The beetle $(0.25 \mathrm{~g})$ was taken into a digestion flask, with $6 \mathrm{ml}$ of concentrated $\mathrm{H}_{2} \mathrm{SO}_{4}$ and a speck of Kjeldah1 catalyst (mixture of $10 \mathrm{~g} \mathrm{Na}_{2} \mathrm{SO}_{4}+5 \mathrm{~g}$ CuSO4+ $0.05 \mathrm{~g}$ selenium). The flask was swirled in order to mix the contents thoroughly then digested on the digestion block till the mixture became clear (colorless or greenish in color). The digest was cooled and transferred to a $100 \mathrm{ml}$ volumetric flask and volume was made up to mark by the addition of distilled water. Distillation of the digest was performed on a Markham Distillation Apparatus. Ten $(10 \mathrm{ml})$ of digest was introduced into the distillation tube then $10 \mathrm{ml}$ of $40 \% \mathrm{NaOH}$ was gradually added through the same way. Distillation was continued for at least 10 min and $\mathrm{NH}_{3}$ produced was collected as $\mathrm{NH}_{4} \mathrm{OH}$ in a conical flask containing $5 \mathrm{ml}$ of $4 \%$ boric acid solution with few drops of methyl red indicator. During distillation yellowish color appeared due to $\mathrm{NH}_{4} \mathrm{OH}$. The distillate was then titrated against standard $0.1 \mathrm{~N} \mathrm{HCI}$ till the appearance of pink color. A blank $(40 \% \mathrm{NaOH}$; $4 \%$ boric) was also run through all steps as above. The nitrogen was determined by micro Kjeldah method and transfer to protein determination by multiplying by a factor of 6.25 . All the proximate values were reported in percentage (\%). Percentage crude protein content of the leaf was determined as follows:

$\%$ Crude Protein $=\quad 6.25 \times \% \mathrm{~N}_{1}$

$\% \mathrm{~N}_{1}=\quad(\mathrm{S}-\mathrm{B}) \times \mathrm{N}_{0} \times 0.014 \times \mathrm{D} \times 100$

Weight of the leaf $x \mathrm{~V}$

Where,

$\mathrm{S}=$ Crude protein titre value

$\mathrm{B}=$ Blank titration reading

$\mathrm{N}_{0}=$ Normality of $\mathrm{HCI}$

$\mathrm{D}=$ Dilution factor

$V=$ Volume of the digest taken for

$0.014=$ Milli equivalent weight of Nitrogen

distillation

Citation: Tsado, A.N., Okoli, N.R., Jiya, A.G., Gana, D., Saidu, B., Zubairu, R., and Salihu, I. Z. (2021). Proximate, Minerals, and Amino Acid Compositions of Banana and Plantain Peels. BIOMED Natural and Applied Science, 01, (01); 032-042 


\section{$6.25=$ Conversion factor from nitrogen to protein $\quad N_{1}=$ Nitrogen content}

\subsubsection{Crude Lipid}

Crude fat was determined by ether extract method using Soxhlet apparatus. Two gram (2g) of moisture free beetle was wrapped in filter paper, placed in fat free thimble and then introduced into the extraction tube. A weighed, cleaned and dried receiving flask was filled with petroleum ether and fitted into the apparatus. The Soxhlet apparatus was assembled and allowed to reflux for 6hrs; extract was transferred into clean glass dish with ether washing which was evaporated on water bath. Then the dish was placed in an oven at $105^{\circ} \mathrm{C}-110^{\circ} \mathrm{C}$ for $1 \mathrm{hr}$ and cooled in a desicator. The percentage crude fat was calculated using the following formula:

$$
\% \text { Crude Fat }=\frac{\text { Weight of ether }}{\text { Weight of plant leaf }} \times 100
$$

\subsubsection{Crude Fibre}

Two grams ( $2 \mathrm{~g}$ ) of the beetles were defatted according to 3.2.1.4 section; the defatted sample was subjected to reflux for 30 mins. The sample was introduced into $200 \mathrm{ml}$ of solution A $\left(2.50 \mathrm{~g} \mathrm{of} \mathrm{H}_{2} \mathrm{SO}_{4}\right.$ in $200 \mathrm{ml}$ of distilled water). The solution was filtered through several layers of cheese cloth on fluted funnel, washed with boiling water until the washings are no longer acidic then the residues were transferred into a beaker and then boiled for $30 \mathrm{~min}$ with $200 \mathrm{ml}$ of solution $\mathrm{B}(2.50 \mathrm{~g}$ of carbonate free $\mathrm{NaOH}$ in $200 \mathrm{ml}$ of distilled water). The final residues were filtered through a thin but close pad of washed and ignited asbestos in a Gooch crucible, then dried in an electric oven and weighed after which it was incinerated, cooled and reweighed. The percentage crude fibre was calculated using the following formula:

$\%$ Crude fibre $=\quad$ Loss in weight after incineration $\times 100$

\subsubsection{Carbohydrate Content}

The carbohydrate content of the beetle was determined by calculation; as percentage difference of the summation of other proximate parameters.

$\%$ carbohydrate $=100-\left(M+P+F+A+F_{2}+L\right)$.

Where

$M=\%$ Moisture, $P=\%$ Protein $F_{1}=\%$ Fat, $A=\%$ Ash, $F_{2}=\%$ Crude Fiber, $L=\%$ Crude Lipid

\subsection{Determination of Amino Acid Profile}

The Amino acid compositions of the samples were determined using methods described by Benitez (1989). The known sample was dried to constant weight, defatted, hydrolyzed, evaporated in a rotary evaporator and loaded into the Applied Biosystems PTH Amino Acid Analyzer. The sample was defatted using chloroform/methanol mixture of ratio $2: 1$. About $500 \mathrm{mg}$ of the sample was put in extraction thimble and extracted for 15 hours in soxhlet extraction apparatus (AOAC, 1995). The defatted sample was weighed into glass ampoule. $7 \mathrm{ml}$ of $6 \mathrm{NHCL}$ was added and oxygen was expelled by passing nitrogen into the ampoule (this is to avoid possible oxidation of some amino acids during hydrolysis e.g methionine and cystine). The glass ampoule was then sealed with Bunsen burner flame and put in an oven preset at $105^{\circ} \mathrm{C} \pm 5^{\circ} \mathrm{C}$ for 22 hours. The ampoule was allowed to cool before broken open at the tip and the content was filtered to remove the humins. It should be 
noted that tryptophan is destroyed by $6 \mathrm{~N} \mathrm{HCL}$ during hydrolysis. The filtrate was then evaporated to dryness using rotary evaporator (AOAC, 1995). The residue was dissolved with $5 \mathrm{ml}$ to acetate buffer $(\mathrm{pH} 2.0)$ and stored in plastic specimen bottles, which were kept in the freezer. A 60 microlitre of the sample was dispensed into the cartridge of the analyzer. The analyzer is designed to separate and analyze free acidic, neutral and basic amino acids of the hydrolysate (Benitez, 1989).

\subsection{Analysis of Mineral composition}

\subsubsection{Calcium}

The calcium content was determined based on the method of Perkin Elmer Corporation, USA (1994). A 1.0g sample was treated with $10 \mathrm{ml}$ of concentrated $\mathrm{HNO}_{3}$ and $4 \mathrm{ml}$ of $70 \% \mathrm{HClO}_{4}$. The resulting solution was evaporated to a smaller volume $(7 \mathrm{ml})$ by careful heating and transferred to $50 \mathrm{ml}$ volumetric flask. One millilitre $(1 \mathrm{ml})$ of $\mathrm{SrCl}_{2} .6 \mathrm{H}_{2} \mathrm{O}$ was added and made up to volume with distilled water. The solution was sprayed into atomic absorption spectrophotometer (Perkin Elmer, model 5100 PCAAS, USA) at $422.7 \mathrm{~nm}$ to determine the concentration of calcium. The calcium standards used were $0 \mathrm{ppm}, 5 \mathrm{ppm}, 10 \mathrm{ppm}, 20 \mathrm{ppm}$ and 30ppm.

\subsubsection{Iron}

The iron content was determined based on the method described by Perkin Elmer Corporation, USA (1994). Ten milliliters $(10 \mathrm{ml})$ of concentrated $\mathrm{HNO}_{3}$ was added to $1 \mathrm{~g}$ of the sample and left overnight. The sample was carefully heated until the production of red nitrogen dioxide fumes ceased. The sample was cooled and $4 \mathrm{ml}$ of $70 \% \mathrm{HClO}_{4}$ was added and evaporated to a smaller volume $(7 \mathrm{ml})$ by careful heating. The resulting solution was quantitatively transferred into $50 \mathrm{ml}$ volumetric flask and diluted to the mark with distilled water. The solution was sprayed into an atomic absorption spectrophotometer (Perkin Elmer, model 5100 PCAAS, USA) at $248.3 \mathrm{~nm}$ to determine the concentration of iron. The iron standards used were $0 \mathrm{ppm}, 1 \mathrm{ppm}, 2 \mathrm{ppm}, 3 \mathrm{ppm}$ and $4 \mathrm{ppm}$.

\subsubsection{Magnesium}

Magnesium was determined by Atomic Absorption Spectrophotometry (AOAC, 1990). One gram (1 g) of the sample was dry ashed in a muffle furnace (Muffle furnace size 2, England) at $550^{\circ} \mathrm{C}$ for 5 hours until a white residue of constant weight was obtained. The minerals were extracted from the ash by adding $20.0 \mathrm{ml}$ of $2.5 \%$ $\mathrm{HCl}$, heated to reduce the volume to $7.0 \mathrm{ml}$, and this was transferred quantitatively to a $50 \mathrm{ml}$ volumetric flask. It was diluted to the mark $(50 \mathrm{ml})$ with distilled water, stored in clean polyethylene bottles and magnesium content determined using atomic absorption spectrophotometer (Perkin Elmer model 5100 PCAAS, USA) at $285.2 \mathrm{~nm}$. Magnesium standards of $0 \mathrm{ppm}, 0.5 \mathrm{ppm}, 1 \mathrm{ppm}, 1.5$, and $2 \mathrm{ppm}$ were used.

\subsubsection{Zinc}

Zinc was determined after digestion of sample (about $2.0 \mathrm{~g}$ ) by Atomic Absorption Spectropho-tometer (AAS) at $213.8 \mathrm{~nm}$ using air-acetylene as a source of flame for atomization (AOAC, 1990). Zinc level was then estimated from standard calibration curve $(0.5-3.0 \mu \mathrm{g} \mathrm{n} / \mathrm{ml})$ prepared from $\mathrm{ZnO}$.

\subsubsection{Sodium}

The sodium determination was done based on the method of AOAC (1995). Two grams of the sample was ashed in muffle furnace (Muffle furnace size 2, England) preheated to $600^{\circ} \mathrm{C}$ for 2 hours. The ash was dissolved in 5 $\mathrm{ml}$ of $5 \mathrm{M} \mathrm{H}_{2} \mathrm{SO}_{4}$. Four millilitres $(4 \mathrm{ml})$ of $2 \%$ ascorbic acid and $4 \mathrm{ml}$ of $4 \%$ ammonium molybdate were added to the resulting solution and shaken for uniform mixing. The absorbance of each sample was determined with a UV spectrophotometer (UNICAM 929 AA Spectrophotometer, UK) at 420nm.

\subsection{Statistical analysis}

Data collected were subjected to statistical analysis using the statistical package for social science version 21.0 and express as mean \pm standard error of mean (SEM). Statistical significance of the results between groups was determined using One-way analysis of variance (ANOVA) followed by Duncans multiple range test (DMRT) Differences in mean were considered to be significant at $p<0.05$.

Citation: Tsado, A.N., Okoli, N.R., Jiya, A.G., Gana, D., Saidu, B., Zubairu, R., and Salihu, I. Z. (2021). Proximate, Minerals, and Amino Acid Compositions of Banana and Plantain Peels. BIOMED Natural and Applied Science, 01, (01); 032-042 


\subsection{RESULTS}

\subsection{Proximate Compositions}

The proximate compositions of plantain and banana peel are shown in Table 4.1: results revealed that carbohydrate is the most abundant proximate contents of both the plantain $(74.12 \pm 0.565)$ and banana $(63.82 \pm 0.32 \%)$ peel, followed by Crude fibre $8.36 \pm 0.04 \%$ and $12.67 \pm 0.08 \%$, crude ash $(6.17 \pm 0.05 \%$ and $9.56 \pm 0.06 \%)$ for both plantain and banana peels respectively. While crude fat $(3.01 \pm 0.06 \%$ and $0.89 \pm 0.04 \%)$ was the least proximate in the both samples. Banana peels contains higher moisture, ash and crude fiber contents than the plantain peel while plantain peel contains higher proteins, fat and carbohydrate contents (Table 1)

Table 1: Proximate composition of banana and plantain peels

\begin{tabular}{lll}
\hline & Plantain peel (\%) & Banana Peel (\%) \\
\hline Moisture & $4.38 \pm 0.03$ & $9.83 \pm 0.03$ \\
Ash & $6.17 \pm 0.05$ & $9.56 \pm 0.06$ \\
Protein & $3.97 \pm 0.07$ & $3.23 \pm 0.05$ \\
Crude fibre & $8.36 \pm 0.04$ & $12.67 \pm 0.08$ \\
Fat & $3.01 \pm 0.06$ & $0.89 \pm 0.04$ \\
Carbohydrate & $74.12 \pm 0.56$ & $63.82 \pm 0.32$ \\
\hline
\end{tabular}

Data are Mean \pm SEM of triplicate determination

\subsection{Minerals Compositions}

The minerals compositions of plantain and banana peel are shown in Table 4.2: Results revealed that sodium is the most abundant minerals contents of both the plantain $(76.88 \pm 0.89 \mathrm{Mg} / 100 \mathrm{~g})$ and banana $(58.16 \pm 2.73$ $\mathrm{Mg} / 100 \mathrm{~g}$ ) peel, followed by magnesium; $45.21 \pm 4.36 \mathrm{Mg} / 100 \mathrm{~g}$ and $49.32 \pm 0.74 \mathrm{Mg} / 100 \mathrm{~g}$, potassium (26.14 \pm 2.68 and $38.22 \pm 0.16)$ for both plantain and banana peels respectively. While iron $(7.89 \pm 0.79 \mathrm{Mg} / 100 \mathrm{~g}$ and $5.06 \pm 0.07 \mathrm{Mg} / 100 \mathrm{~g}$ ) was the least minerals in the both samples. Banana peels contains higher manganese, magnesium, calcium and potassium while other minerals were higher in plantain peel (Table 2).

Table 2: Mineral composition of banana and plantain peels

\begin{tabular}{llll}
\hline & $\begin{array}{l}\text { Banana } \\
(\mathbf{M g} / \mathbf{1 0 0 g})\end{array}$ & $\begin{array}{l}\text { Plantain } \\
(\mathbf{M g} / \mathbf{1 0 0 g})\end{array}$ & peel \\
\hline Copper & $1.35 \pm 0.05$ & $0.59 \pm 0.83$ \\
Iron & $5.06 \pm 0.07$ & $7.89 \pm 0.79$ \\
Manganese & $10.38 \pm 0.04$ & $1.25 \pm 0.39$ \\
Zinc & $11.60 \pm 0.03$ & $13.30 \pm 0.57$ \\
Calcium & $17.85 \pm 0.25$ & $14.70 \pm 0.25$ \\
Magnesium & $49.32 \pm 0.74$ & $45.21 \pm 4.36$ \\
Sodium & $58.16 \pm 2.73$ & $76.88 \pm 0.89$ \\
Potassium & $38.22 \pm 0.16$ & $26.14 \pm 2.68$ \\
phosphorus & $22.64 \pm 0.38$ & $28.95 \pm 0.94$ & \\
\hline
\end{tabular}

Data are Mean \pm SEM of triplicate determination

\subsection{Amino acid compositions}

The amino acid compositions of plantain and banana peel are shown in Table 3: Results revealed that the total amino acid of $89.71 \pm 5.45 \mathrm{~g} / 100 \mathrm{~g}$ and $86.71 \pm 3.02 \mathrm{~g} / 100 \mathrm{~g}$ was recorded for plantain and banana peel. Glutamic acid $12.72 \pm 0.02 \mathrm{~g} / 100 \mathrm{~g}$ was the most abundant amino acid in plantain peel followed by leucine $(7.76 \pm 0.05$ $\mathrm{g} / 100 \mathrm{~g})$ and lysine $(7.90 \pm 0.03 \mathrm{~g} / 100 \mathrm{~g})$, however, in banana peel, glycine $(3.02 \pm 0.82 \mathrm{mg} / 100 \mathrm{~g})$ was the most abundant amino acid followed by aspartic acid $(9.06 \pm 0.05 \mathrm{~g} / 100 \mathrm{~g})$ and lysine $(6.71 \pm 0.06 \mathrm{~g} / 100 \mathrm{~g})$.

Citation: Tsado, A.N., Okoli, N.R., Jiya, A.G., Gana, D., Saidu, B., Zubairu, R., and Salihu, I. Z. (2021). Proximate, Minerals, and Amino Acid Compositions of Banana and Plantain Peels. BIOMED Natural and Applied Science, 01, (01); 032-042 
Table 3: Amino acid composition of banana and plantain peels

\begin{tabular}{lll}
\hline Amino Acid & $\begin{array}{l}\text { Plantain peel } \\
\mathbf{( g / 1 0 0 g} \text { protein) }\end{array}$ & $\begin{array}{l}\text { Banana Peel } \\
\text { (g/100g protein) }\end{array}$ \\
\hline Leucine & $7.76 \pm 0.05$ & $0.01 \pm 0.00$ \\
Lysine & $7.90 \pm 0.03$ & $6.71 \pm 0.06$ \\
Isoleucine & $5.24 \pm 0.05$ & $8.06 \pm 0.04$ \\
Phenylalanine & $4.79 \pm 0.06$ & $4.98 \pm 0.07$ \\
Norleucine & $0.02 \pm 0.00$ & $5.23 \pm 0.06$ \\
Trytophan & $0.58 \pm 0.03$ & $0.01 \pm 0.00$ \\
Valine & $5.67 \pm 0.01$ & $0.52 \pm 0.02$ \\
Methionine & $1.60 \pm 0.03$ & $5.79 \pm 0.03$ \\
Proline & $3.25 \pm 0.02$ & $1.71 \pm 0.02$ \\
Arginine & $4.99 \pm 0.03$ & $3.25 \pm 0.05$ \\
Tyrosine & $3.96 \pm 0.06$ & $5.50 \pm 0.03$ \\
Histidine & $2.11 \pm 0.04$ & $3.96 \pm 0.01$ \\
Cystine & $0.85 \pm 0.02$ & $2.24 \pm 0.03$ \\
Alanine & $6.22 \pm 0.05$ & $0.85 \pm 0.04$ \\
Glutamic acid & $12.72 \pm 0.02$ & $5.31 \pm 0.01$ \\
Glycine & $3.94 \pm 0.01$ & $13.02 \pm 0.82$ \\
Threonine & $5.38 \pm 0.06$ & $6.10 \pm 0.03$ \\
Serine & $4.05 \pm 0.04$ & $4.59 \pm 0.04$ \\
Aspartic acid & $8.68 \pm 0.02$ & $9.06 \pm 0.05$ \\
Total & $89.71 \pm 5.45$ & $86.71 \pm 3.02$ \\
\hline Data & &
\end{tabular}

Data are Mean \pm SEM of triplicate determination

\subsection{Discussion}

The moisture content of foods or its processed products gives an indication of its freshness and shelf life, and high moisture content subjects food items to increased microbial spoilage and short shelf life, which can lead to its deterioration (Adepoju and Onasanya, 2008). The high moisture contents of banana peel as compared with plantain peel is an indication that plantain peel would be less susceptible to microbial attacked and thus the shelf-life of the plantain peel would be higher than that of the banana peel

Protein is an essential component of diet needed for survival of animals and human being, their basic function in nutrition is to supply adequate amount of required amino acids. The protein contents of both plantain and banana peel was high in crude protein when compared with other sources of plant protein. They are higher than that of Shea butter fruit pulp (Ketiku, 1973), amaranthus and cocoyam leaves (Adepoju et al., 2006). However, the protein content of banana ripe peel and plantain peel was low compared with that of other widely eaten staple roots, tubers and fruits (Aurand, 1987) and fluted pumpkin pod and pulp (Essien et al., 1992).

The crude fat content of the banana and plantain peels were very low and may not be good source of fat-soluble vitamins nor can contribute significantly to energy content of the feeds that can be prepared with the wastes. These low-fat contents will increase the storage life of the peels by reducing the chances of developing rancidity.

Results of the present study indicated that carbohydrate is the most abundant proximate contents of both the plantain (74.12 \pm 0.565$)$ and banana $(63.82 \pm 0.32 \%)$ peel. These high carbohydrate contents are an indication of good sources of energy for the humans and animals. The ash content of the samples was comparatively higher than those reported by previous researchers for agricultural hull (Adebowale and Bayer, 2002) and banana peels (Adeyi and Oladayo, 2010). The high values of the ash were indicative of high mineral (especially the macrominerals) content of the peels.

Results of the present study indicated that the crude fibre $8.36 \pm 0.04 \%$ and $12.67 \pm 0.08 \%$ was the second most abundant proximate contents of banana and plantain peels, these values were comparably higher than the value obtained for plant products such as Ube (Dacryodes edulis) $(2.1 \mathrm{~g} / 100 \mathrm{~g}$, Adepoju and Adeniji, 2008) and fruit pulp, $(4.3 \mathrm{~g} / 100 \mathrm{~g})$. High fibre content in diets have been reported to result in increased removal of potential Citation: Tsado, A.N., Okoli, N.R., Jiya, A.G., Gana, D., Saidu, B., Zubairu, R., and Salihu, I. Z. (2021). Proximate, Minerals, and Amino Acid Compositions of Banana and Plantain Peels. BIOMED Natural and Applied Science, 01, (01); 032-042 
mutagens, steroids and xenobotics by binding or absorbing to dietary fibre components and thereby aids digestion; hence these banana and plantain peels will have health promoting benefits for human, livestock and fish farming (Haslinda et al., 2009).

The analysis of mineral content of the peels indicated that sodium is the most abundant minerals contents of both the plantain $(76.88 \pm 0.89 \mathrm{Mg} / 100 \mathrm{~g})$ and banana $(58.16 \pm 2.73 \mathrm{Mg} / 100 \mathrm{~g})$ peel, followed by magnesium; $45.21 \pm 4.36 \mathrm{Mg} / 100 \mathrm{~g}$ and $49.32 \pm 0.74 \mathrm{Mg} / 100 \mathrm{~g}$, potassium (26.14 \pm 2.68 and $38.22 \pm 0.16$ ) for both plantain and banana peels respectively. While iron $(7.89 \pm 0.79 \mathrm{Mg} / 100 \mathrm{~g}$ and $5.06 \pm 0.07 \mathrm{Mg} / 100 \mathrm{~g}$ ) was the least minerals in the both samples. Calcium and phosphorus are very important in the formation of strong bones and teeth, for growth, blood clotting, heart function and cell metabolism (Rolfe et al., 2009). Potassium is an important raw material in soap production and in soil neutralization (Adeolu and Enesi, 2013). The iron level of the peel was higher than the values recorded for dry guinea corn leaf extracts (1.2mg -2.1mg/100g, Adepoju, 2007) and fresh and roasted Dacryodes edulis fruit (7.0mg and 3.0mg/100mg respectively) (Adepoju and Adeniji, 2008). Therefore, banana and plantain peels been rich in macrominerals, it can also be formulated into instant flours for convalescence and in the formulation of baby foods as these categories of humans require high levels of minerals for growth and repair.

This study indicated that the plantain and banana peels contain all the essential amino acids when referred to the classification of the FAO/WHO Committee (FAO/WHO, 2001). Results revealed that the total amino acid of $89.71 \pm 5.45 \mathrm{~g} / 100 \mathrm{~g}$ and $86.71 \pm 3.02 \mathrm{~g} / 100 \mathrm{~g}$ was recorded for plantain and banana peel. Glutamic acid $12.72 \pm 0.02 \mathrm{~g} / 100 \mathrm{~g}$ was the most abundant amino acid in plantain peel followed by leucine $(7.76 \pm 0.05 \mathrm{~g} / 100 \mathrm{~g})$ and lysine $(7.90 \pm 0.03 \mathrm{~g} / 100 \mathrm{~g})$, however, in banana peel, glycine $(3.02 \pm 0.82 \mathrm{mg} / 100 \mathrm{~g})$ was the most abundant amino acid followed by aspartic acid $(9.06 \pm 0.05 \mathrm{~g} / 100 \mathrm{~g})$ and lysine $(6.71 \pm 0.06 \mathrm{~g} / 100 \mathrm{~g})$. Hence, these values obtained corroborate those observed by Sheng et al., (2010), who noticed that banana peels contained all the essential amino acids. This suggests that the powders of these banana and plantains peels could be introduced like food supplements into the pap of children in order to enrich their feeding

\subsection{Conclusion}

The banana and plantain peels were rich in crude fibre, carbohydrates and ash and can serve as basal materials or components of human animal feed. The banana peel was high in sodium, magnesium, potassium, calcium and phosphorus, and can be good source of these minerals. Banana and plantain peels pose to be potential good sources of nutrients for production of human and animal feeds, and their utilization for this purpose should be encouraged, as this will also help in reducing the menace of nutrient deficiencies and environmental waste management. Based on results obtained in this study, it is recommended that studies on the bioavailability of nutrients in banana and plantains peels are needed. Similarly, antinutrients compositions of these peel should be evaluated. The use of these peels in nutrients formulation should be carried out and evaluated for vivo malnutrition study

\section{References}

Adebowale, K.O., and Bayer, E. (2002). Active carbons from low temperature conversion chars. Electronic Journal of Environronmental Agriculture and Food Chemistry, 7(11), 3304-3315.

Adeniji, T.A., Sanni, L.O., Barimalaa, I.S., and Hart, A.D. (2006). Determination of micronutrients and colour variability among new plantain and banana hybrids flours. World Journal Chemistry,1(1): 23-27.

Adeolu, A.T., and Enesi, D.O. (2013). Assessment of proximate, mineral, vitamin and phytochemical compositions of plantain (Musa paradisiaca) bract - an agricultural waste. International Research Journal of Plant Science 4(7), 192- 197.

Adepoju, O.T., and Adeniji, P.O. (2008). Nutrient composition, anti-nutritional factors and contribution of native pear (Dacryoides edulis) pulp to nutrient intake of consumers. Nig Journal of Nutritional Science, 29(2), $15-23$.

Adepoju, O.T., and Onasanya, L.O. (2008). Nutrient composition and antinutritional factors of corn leaf extract to nutrient intake of consumers. Nigeria Journal of Nutritional Sciences, 28(1).

Citation: Tsado, A.N., Okoli, N.R., Jiya, A.G., Gana, D., Saidu, B., Zubairu, R., and Salihu, I. Z. (2021). Proximate, Minerals, and Amino Acid Compositions of Banana and Plantain Peels. BIOMED Natural and Applied Science, 01, (01); 032-042 
Adepoju, O.T., Onasanya, L.O., and Udoh, C.H. (2006). Comparative studies of nutrient composition Adepoju OT (2007). Nutrient composition, anti-nutritional factors and contribution of dry guinea

Adeyi, O. (2010). Proximate composition of some agricultural wastes in Nigeria and their potential use in activated carbon production. Journal of Applied. Science and Environmental Management. 14(1), 5558.

AOAC (1990). Official Methods of Analysis of the Association of Official Analytical Chemists, 15th ed., AOAC, Arlington, Virginia, USA.

AOAC, (1995). Official methods of analysis (15th edn) Association of Official Analytical Chemists. Arlington, V. A. USA.

Aurand, W.L. (1987). Food composition and analysis of food, Von Nostrand Reinhold, New York, pp.135-138.

Benitez, L. V. (1989). Amino acid and fatty acid profiles in aquaculture nutrition studies. Fish nutrition research in asia, 23-35.

Essien, A.I., Ebana, R.U.B., and Udo, H.B. (1992). Chemical evaluation of pod and pulp of the fluted pumpkin (Telfaira occidentalis) fruit. Food Chemistry, 45, 175-178.

FAO/WHO (2001). Human vitamin and mineral requirements. Report of a joint FAO/WHO expert consultation Bangkok, Thailand, 281p.

Florenta, A.W., Loha, A.M., and Thomas, H.E. (2015). Nutritive Value of three varieties of banana and plantain blossoms from Cameroon. Greener Journal of Agricultural Sciences, 5 (2), pp. 052-061

Gill, L.S. (1992). Ethnomedicinal uses of plants in Nigeria. University of Benin Press, Benin City, Nigeria,. pp. 169-170, 1992.

Haslinda, W.H., Cheng, L.H., Chong, L.C., and Noor Aziah, A.A. (2009). Chemical composition and physicochemical properties of green banana flour. International Journal. Of Food sciences and Nutrition, 60(S4): 232-239.

Ketiku, A.O. (1973). Chemical composition of unripe and ripe plantain (Musa paradisiaca). . Journal of Science and food Agriculture, 24, 703-707.

Lim, R.H. (2009). Fabrication and Characterization of Biodegradable Composite Film From Banana Stem, Dissertation, Universiti Malaysia Pahang, 2009.

Ng, S.P., and Fong CS (2000). Banana enhances your anti-cancer power. In: Health discovery. Petaling Jaya Malalysia: Life Publisher Berhad. of cocoyam (Colocassia esculenta) leaf with some green leafy vegetables. Nigeria Journal of Nutritional Sciences, 27 (1), $22-26$.

Oladiji, A.T., Idoko, A.S., Abodunrin, T.P., and Yakubu, M.T. (2010).Studies on the physicochemical properties and fatty acid composition of the oil from ripe plantain peel(Musa paradisiaca). African Scientist, 11(1) 73-78.

Omole, A.J., Ajasin, F.O., Oluokun, J.A., and Obi, O.O. (2008) Performance characteristics of weaned rabbit fed plantain peel as replacement for maize. Journal of nutrition and Food. 38:559-563.

Osma, J.F., Herrera, J.L.T., and Couto, S. (2007). Banana skin: A novel waste for lactase production by Tramets pubescens under solid-state conditions. Application to synthetic dye decolouration. Dye pigments \&5:3237.

Panda, D. (2013). Removal of Lead From Polluted Water Using Waste Eggshell, Thesis Master of Science in Physics, National Institute of Technology Rourkela.

Citation: Tsado, A.N., Okoli, N.R., Jiya, A.G., Gana, D., Saidu, B., Zubairu, R., and Salihu, I. Z. (2021). Proximate, Minerals, and Amino Acid Compositions of Banana and Plantain Peels. BIOMED Natural and Applied Science, 01, (01); 032-042 
Philips, T.A. (1982). An Agricultural Notebook. Longman, Nigeria p.125. plantains (Musa spp) as determined by instrumental neutron activation analysis. Journal of Radioanalytical and Nuclear Chemistry, 270(2): 407411.

Rolfes, S.R., Pinna, K., and Whitney, E. (2009). Understanding normal and clinical nutrition. Eighth, A.R., and Townsend, C.E. (2003). Nutrition and diet therapy 8th edn. Delmar Learning, Thomson Learning Inc. Canada. Pp 132 and cover page.

Steven, A.M. (2012). Biodegradable Mulch Film Made From Bioplastics Petition submitted to National List Manager USDA/AMS/NOP (2012)

Swennen R(1990). Limits of mophotaxonomy of plantain in Africa and elsewhere. Genet. Res. Crop Evol. 18: 172-210.

Copyright (c) 2021 Tsado et al. This is an open access article distributed under the terms and conditions of the Creative Commons Attribution License (CC BY) which allowed unrestricted download, distribution and reused as long as the original authors are properly cited.

Citation: Tsado, A.N., Okoli, N.R., Jiya, A.G., Gana, D., Saidu, B., Zubairu, R., and Salihu, I. Z. (2021). Proximate, Minerals, and Amino Acid Compositions of Banana and Plantain Peels. BIOMED Natural and Applied Science, 01, (01); 032-042 